\title{
FACTORS THAT AFFECT THE FINANCING VOLUME IN THE SHARIA COMMERCIAL BANKS
}

\author{
Maya Indriastuti \\ maya@unissula.ac.id \\ Indri Kartika \\ Faculty of Economics, Universitas Islam Sultan Agung \\ J1. Kaligawe Raya, Semarang 50112, Indonesia
}

received: 14/05/18; revised: 20/06/18; published: 27/06/18

\begin{abstract}
The aims of this research are to analyze the effect of the Non Performing Financing (NPF), Financing to Deposit Ratio (FDR), and Third-Party Funds (TPF) to the volume of financing of Sharia Banks in Indonesia. The data used is an annual report from Sharia Commercial Banks in the year of 2014 to 2016, were analyzed by multiple regression analysis. The results of this study indicate that the NPF has a positive insignificant to the volume of financing of Sharia Commercial Banks in Indonesia, FDR and TPF have a positive and significant to the volume of financing of Sharia banks in Indonesia. The implications of this research are for Sharia Commercial Banks to be able to consider the determination of corporate policies and improving operational performance in order to improve the financial performance of the company, especially related to the variables studied and its effects for them.
\end{abstract}

Keywords: financing volume; non performing financing; financing to deposit ratio; third-party funds; sharia commercial banks

\section{INTRODUCTION}

Financing is the main activity of banks that generate revenue for Islamic banks. Investment of funds to other parties in the form of financing has a default risk of the financing customer (Law No. 10 about Banking, 1998). According to (Law No. 10 about Banking, 1998) financing is the provision of money or equivalent claims, based on an agreement or agreement between the bank and other parties financed to refund the money or invoice after a certain period of time in exchange for a fee or profit share. Within sharia banking, the financing provided to users is based on sharia principles, the rules used are in accordance with Islamic law.

Expectations of sharia banks on the distribution of financing is not as smooth as what it wants, because the highest rating on Islamic bank financing is financing second-order financing is the financing for the results and the lowest is rental financing. This is based on sharia banking statistics data published by OJK until December 2014 , financing with the principle of sale and purchase of 750,371 , namely murabahah financing $117.371 \%$, salam $0 \%$, istishna $633 \%$. Distribution financing of $63.741 \%$, that are mudhorobah financing $14.354 \%$, musyarokah financing $49.387 \%$.
However, in terms of different positive growth marked the development of sharia banking in 2016 after the last 3 years experienced a slowdown in growth. The growth of assets and deposits of the national sharia banking industry in 2016 consisting of Bank Umum Syariah (BUS), Unit Usaha Syariah (UUS), and Bank Pembiayaan Rakyat Syariah (BPRS) each experienced growth of $20.28 \%, 16.41 \%$, and $20.84 \%$. The total assets of the national sharia banking industry in 2016 reached Rp. 365.6 trillion, PYD of Rp254.7 trillion and DPK of Rp 285.2 trillion. Likewise, the quality of financing, capital, profitability, liquidity, and efficiency level of sharia banking is reflected in the improved ratio of NPF, CAR, ROA, FDR and BOPO of sharia banking (Otoritas Jasa Keuangan, 2016), those same with (Al-Jarhi, 2014) that sharia banks better than convensional banks.

(Nikensari, et.al., 2012) said that NPF had no significant effect on the amount of mudarabah financing, because Non-performing Financing (NPF) used rescheduling and reconditioning scheme and financing into qordhul hasan. (Lusian, et.al., 2015) found that NPF has a significant impact to the financial returns. (Giannini, 2013) and (Sri, et.al., 2013) said that NPF variable does not affect the financing. (Nuryantono, et.al., 2016) found that non performing financing ratios as well as business services and social service sector. 
(Husaeni, 2016) found that variables of nonperforming financing have a negative effect but insignificant to the Murabaha financing. Non Performing financing increase due to unoptimal collection of deposits (Lusian, et.al., 2015). Different with (Havidz and Setiawan, 2015) that non performing financing increase due to size, operational efficiency ratio, and GDP growth rate. (Baehaqie, et.al., 2017), non performing financing has a positive and significant to the deposit level. The NPF variable has a positive relationship is not significant to the financing (Ghenimi and Omri, 2015). This research same with (Akhtar,et.al., 2011) that NPF variable has a positive effect but not significant to the financing.

The research from (Wiranatakusuma and Duasa, 2017) found that the resistance of Islamic banking on external factors, thera are deposits and financing. (Giannini, 2013) said that FDR variable negatively affects financing. (Husaeni, 2016) found that variable of FDR has a positive sign to the financing. In addition, the development of Islamic banks has also been supported by the legal basis with the issuance (Law No. 21 about Syariah Banking, 2008) on sharia banking issued on July 16,2008 . The existence of the Act will encourage the growth of Islamic banks evidenced by the development of Islamic banks impressive with average asset growth of more than $65 \%$ per year. The growth of sharia banks is of course influenced by various factors. The availability of Third Party Funds (TPF) becomes one of the important factors affecting the fulfillment of sufficiency of sharia bank financing fund. The higher the ratio of Third Party Funds, the better the level of public confidence in the bank concerned because the Third Party Fund is the main source of funds for the bank derived from public funds. (Husaeni, 2016) concluded that third-party funds have a significant positive effect on financing. This is in line with the findings (Sri Anastasya, 2013) that third party funds have a positive effect on financing.

Based on previous findings, this study is intended to analyze and empirically examine the factors affecting the financing volume of sharia banks in Indonesia.

(Giannini, 2013) and (Sri, et.al., 2013) said that NPF variable does not affect the financing. (Nuryantono, et.al., 2016) found that non performing financing ratios as well as business services and social service sector. (Husaeni, 2016) found that variables of nonperforming financing have a negative effect but insignificant to the Murabaha financing. Non Performing financing increase due to unoptimal collection of deposits (Lusian, et.al., 2015). The capability of the bank to collect deposit is very crucial for its intermediary function. (Havidz and Setiawan, 2015) told that non performing financing was affected by size, operational efficiency ratio, and GDP growth rate. (Baehaqie, et.al., 2017), non performing financing has a positive and significant to the deposit level. The NPF variable has a positive relationship is not significant to the financing (Ghenimi and Omri, 2015). (Akhtar, et.al., 2011) that NPF variable has a positive effect but not significant to the financing.

The higher NPF ratio, indicate the quality of sharia bank financing is getting worse. The high NPF ratio resulted in the smooth operation of sharia bank business to be disturbed, so the level of bank health becomes decreased. Due to the high NPF, banks must provide greater reserves, so that in the end the bank's capital will be eroded. The amount of capital greatly affects the amount of credit expansion or financing. As a result, banks will be more cautious or selective in the process of financing to avoid the risk of problem financing. This is due to the potential for uncollectible financing.

H1: NPF negatively affects the financing volume of Sharia Commercial Bank.

Banks with a very high FDR, then the bank will have the risk of uncollectible loans so high that at some point the bank will incur losses. Therefore, Bank Indonesia in the Bank Indonesia Regulation of 2013 has set the standard for FDR, which ranges from $78 \%$ to $92 \%$. Thus FDR is predicted to have a significant effect on the distribution of financing or credit.

The research from (Wiranatakusuma and Duasa, 2017) found that the resistance of Islamic banking on external factors, thera are deposits and financing. (Giannini, 2013) said that FDR variables negatively affect financing. (Husaeni, 2016) found that variables of FDR have a significant positive to the financing. FDR is a factor to measure bank soundness in liquidity. FDR is also related to the distribution of financing because of the activities of the distribution of financing or lending banks can meet its short-term obligations, repay all depositors who took funds at any time, and meet the credit proposed.

H2: FDR negatively affects the financing volume of Sharia Commercial Banks.

(Husaeni, 2016) states that third party funds have a significant positive effect on financing. This is in line with the findings of (Sri, et.al., 2013) that third party funds have a positive effect on financing. The activities of banks after collecting funds from the wider community are channeling the funds back to the communities that need them, in the form of financing. So, as higher as the level of DPK of a Syariah bank, it will be higher the amount of financing done by the sharia bank.

H3: TPF positively affects the financing volume of Sharia Commercial Banks.

\section{METHODS}

This study is a quantitative study on Syariah commercial banks in Indonesia using secondary data analysis derived from the financial statements of sharia banks in Indonesia. Determination of the sample in this 
study uses census method, where the population of the sample with dama, obtained 11 sharia commercial banks active from 2014-2016 in Indonesia.

a. Non Performing Financing (NPF) is a ratio that describes the amount of nonperforming financing to the total financing provided by the bank (Giannini, 2013). The formula:

$$
\mathrm{NPF}=\frac{\text { Total Credits }}{\text { Troubled Credit }}
$$

b. Financing to Deposit Ratio (FDR) is the ratio between the amount of financing provided by the bank and the third party funds received by the bank (Giannini, 2013). The formula is:

$$
\mathrm{FDR}=\frac{\text { Total Third Party Funds disbursed }}{\text { Amount of Financing }}
$$

c. Third Party Funds (TPF) represent non-bank third party deposits consisting of demand deposits, savings deposits, and time deposits. The value can be seen in the position of Islamic bank TPF at the end of the period expressed in billion rupiahs (Husaeni, 2016).

d. Financing Volume

The position of the volume of financing or total financing disbursed by the Sharia Commercial Bank at the end of the period.

This research uses multiple linear regression analysis techniques (Ghozali, 2013) with the following equation:

$$
\mathrm{Y}=\mathrm{a}+\mathrm{b} 1 \mathrm{X} 1+\mathrm{b} 2 \mathrm{X} 2+\mathrm{b} 3 \mathrm{X} 3+\varepsilon
$$

note :

$\mathrm{Y}=$ Financing of Sharia Commercial Bank

$\mathrm{X} 1=$ Non performing financing $(\mathrm{NPF})$

$\mathrm{X} 2$ = Financing to deposit ratio (FDR)

$\mathrm{X} 3=$ Third Party Funds (TPF)

$\mathrm{b} 1=\mathrm{NPF}$ coefficient

$\mathrm{b} 2=$ FDR coefficient

b3 $=$ TPF coefficient

$\mathrm{a}=$ Constant (intercept)

$\varepsilon \quad=$ Residual

\section{RESULTS}

Based on regression test result, regression equation can be made as follows:

$$
\mathrm{Y}=-0,414+0,025 \mathrm{NPF}+0,238 \mathrm{FDR}+0,299 \mathrm{TPF}
$$

The result of statistical computation showed $\mathrm{F}$ count $=4,445$ with significance of 0,001 . It means that, NPF, FDR, and TPF simultaneously have positive significant effect on volume financing (table 1).
Table 1. F Statistical Test ANOVA $^{\mathrm{b}}$

\begin{tabular}{rlrrrrl}
\hline & & Sum of & & Mean & & \\
\multicolumn{1}{l}{ Model } & Squares & Df & Square & F & Sig. \\
\hline 1 & Regression & 6.122 & 3 & .529 & 4.445 & $.001^{\mathrm{a}}$ \\
& Residual & 6.221 & 30 & .319 & & \\
& Total & 12.763 & 33 & & & \\
\hline
\end{tabular}

Source: data, 2018

The value of determination coefficience (adjusted R2) was 0,510 which means that only $51 \%$ of financing volume in this research could be determined by the 3 variables (NPF, FDR, and TPF), while other 49\% of financing volume could be determined by other variables (Table 2).

Table 2. Determination Coefficience Model Summary ${ }^{\mathrm{b}}$

\begin{tabular}{cccccc}
\hline Model & $\mathrm{R}$ & $\begin{array}{c}\mathrm{R} \\
\text { Square }\end{array}$ & $\begin{array}{c}\text { Adjusted } \\
\text { R Square }\end{array}$ & $\begin{array}{c}\text { Std. Error of } \\
\text { the Estimate }\end{array}$ & $\begin{array}{c}\text { Durbin- } \\
\text { Watson }\end{array}$ \\
\hline 1 & $.868^{\mathrm{a}}$ & .675 & .510 & .67681 & 1.842 \\
\hline
\end{tabular}

\begin{tabular}{|c|c|c|c|c|c|c|}
\hline & & \multicolumn{2}{|c|}{$\begin{array}{c}\text { Unstandardized } \\
\text { Coefficients }\end{array}$} & \multicolumn{3}{|l|}{$\begin{array}{l}\text { Standardized } \\
\text { Coefficients }\end{array}$} \\
\hline \multicolumn{2}{|c|}{ Model } & B & $\begin{array}{l}\text { Std. } \\
\text { Error }\end{array}$ & Beta & $\mathrm{t}$ & Sig. \\
\hline \multirow[t]{4}{*}{1} & (Constant) & -.414 & .803 & & .138 & .991 \\
\hline & NPF & .025 & 2.324 & .133 & 1.619 & .190 \\
\hline & FDR & .238 & 4.153 & .382 & 3.737 & .001 \\
\hline & TPF & .299 & 5.471 & .482 & 4.154 & .000 \\
\hline
\end{tabular}

Source: data, 2018

The result of $\mathrm{t}$ test showed in Table 3 .

Table 3. t Statistical Test

Source: data, 2018

Based on the regression output obtained value $t$ arithmetic NPF variable of 1.619 and the value of sig. $t$ arithmetic of 0.190 greater than the value of alpha $(\alpha)=0.05$, it can be concluded that the variable NPF positively insignificant effect on the volume of financing of sharia banks.

Regression output obtained value $t$ arithmetic FDR variable of 3.737 and the value of sig. $t$ arithmetic of 0.001 is smaller than the value of alpha $(\alpha)=0.05$. With $t$ arithmetic has a positive coefficient direction, it can be concluded that the variable FDR have a significant positive effect on the volume of financing of sharia banks.

Regression output obtained value $\mathrm{t}$ arithmetic variable TPF is 4.154 and sig value. $t$ arithmetic of 0.000 smaller than the value of alpha $(\alpha)=0.05$. With 
t arithmetic has positive coefficient direction, it can be concluded that TPF variable has a significant positive effect on the volume of financing of sharia bank.

\section{DISCUSSION}

The result of the test with regression analysis shows that NPF has no significant positive effect on the volume of financing of sharia bank in Indonesia. The test results also contradict the hypothesis that has been formulated in this study, which states that the NPF negatively affect the volume of financing of sharia banks. The first hypothesis was rejected due to differences in NPF characteristics among sharia commercial banks, where there are some sharia banks that have NPF values that tend to increase and others tend to decrease.

The results of this study are in line with (Baehaqie, et.al., 2017) which concludes that NPF has a significant positive effect. But unlike the results of research (Husaeni, 2016) state that the NPF has a negative effect is insignificant on financing. (Sri, et.al., 2013) also stated that the NPF had a non-significant negative effect on financing. The same results are also shown by (Giannini, 2013) that NPF has no effect on financing. The results of (Purbaningsih, 2014) states that NPF has no significant negative effect on financing.

Test results with regression analysis showed that FDR has a significant positive effect on the financing volume of sharia banks in Indonesia. The results are in line with research conducted by (Husaeni, 2016) which states that FDR has a significant positive effect on financing, but contradicts the hypothesis concluded in this study, since the average FDR value of sharia banks in this study is already within the limits the ideal of Bank Indonesia regulation in 2013, which ranges between $78 \%$ - 92\%, and also because most customers of sharia banks are loyal customers, so it is not the main consideration of sharia bank management in making decisions regarding the distribution of financing. In contrast (Giannini, 2013) states that FDR negatively affects financing.

The test results show that TPF (Third Party Fund) has a significant positive effect on the volume of financing of sharia banks in Indonesia. The results of this analysis are in accordance with the hypothesis that has been formulated previously. The research that has been done previously, namely by (Husaeni, 2016) that the TPF has a positive effect on the volume of financing. (Sri, et.al., 2013) also showed similar results. Third Party Fund (TPF), is a market share of third-party funds collected by individual banks individually. The higher this ratio, the better the level of public confidence in the bank concerned. The activities of banks after collecting funds from the wider community are channeling the funds back to the communities that need them, in the form of financing. So, as high as the TPF level of a Syariah bank will be as high as amount of financing done by the sharia bank.
The effect of the positive and significant amount of third-party funds on financing volume is in accordance with the theory that the TPF is the main source of Islamic banking funding. Therefore Islamic banks are in dire need of funds sourced from third parties. Sharia banks as financial institutions have a high priority in allocating funds to financing disbursements. This is because the main source of profit banking sector obtained through the provision of credit to the community. Because Islamic banks are in dire need of funds to be channeled back. The main source of funds is obtained through a third party, in this case, the community as depositors who deposit funds in the bank. In performing its function as an intermediary between the surplus party and the sharia bank deficit has many products that lead to the collection of third-party funds. The greater the funds raised from the community, the greater the funds that can be disbursed by Islamic banks through financing.

\section{CONCLUSION}

The results of research and discussion, it can be concluded that the NPF (Non-Performing Financing) positively affect the volume of financing at sharia commercial banks in Indonesia. Furthermore, FDR (Financing to Deposit Ratio) has no effect on the financing volume of sharia banks in Indonesia. TPF (Third Party Fund) has a positive effect on the financing volume of sharia banks in Indonesia. The results of this study can provide benefits for Islamic banks themselves to be able to consider the determination of corporate policies and improve operational performance in order to improve the financial performance of the company, especially related to the variables studied and its effects for Islamic banks.

\section{REFERENCES}

Akhtar, Muhammad Farhan, Ali, Khizer, and Sadaqat, S., 2011. Liquidity Risk Management: A comparative study between Conventional and Islamic Banks of Pakistan. Interdiscip. J. Res. Bus. 1, 35-44.

Al-Jarhi, M.A.M.M., 2014. Towards an Economic Theory of Islamic Finance Regulation. J. Islam. Bank. Financ. 2, 345-366.

Anastasya, S., 2013. The Influence of Third Party Funds, CAR, NPF, and ROA Against The Financing of A General Sharia-Based Bank in Indonesia. In: International Conference on Business, Economics and Accounting 20-23 March 2013.

Baehaqie Sofyan, Fahmi Idqan, and B.S.I., 2017. Determining Factors of Deposit Level of Islamic Bank in Indonesia. Al-Istishad J. Ilmu Ekon. Syariah (Journal Islam. Econ. 9, 213-226.

Ghenimi, Ameni and Omri, M.A.B., 2015. Liquidity Risk Management: A Comparative Study between Islamic and Conventional Banks. J. Bus. Manag. Econ. 3, 25-30. 
Ghozali, I., 2013. Analisis Multivariate dengan Program SPSS. Fakultas Ekonomi Universitas Diponegoro.

Giannini, N, 2013. Faktor yang Mempengaruhi Pembiayaan Mudharabah pada Bank Umum Syariah di Indonesia. Account. Anal. J. 1.

Havidz, Shinta Amalina Hazrati and Setiawan, C., 2015. Bank Efficiency and Non-Performing Financing (NPF) In The Indonesian Islamic Banks. Asian J. Econ. Model. 3, 61-79.

Husaeni, A.U., 2016. The Variables that Affect Murabaha Financing in Islamic Commercial Banks. Int. J. Nusant. Islam 4.

Law No. 10 about Banking, 1998.

Law No. 21 about Syariah Banking, 2008.

Lusian, S., Siregar, H. and Maulana, T.N.A., 2017. Analisis Faktor-faktor Penyebab Pembiayaan Bermasalah di Bank Pembiayaan Rakyat Syariah XYZ periode 2009 - 2013. Jurnal Keuangan dan Perbankan, 16(1).
Nikensari, Sri Indah, D.S. dan T.S., 2012. Pembiayaan Mudharabah dan Kaitannya dengan NPF dan Bagi Hasil. J. Econo Sains X.

Nuryartono, N., Saptono, I.T. and Wasan, G.H., 2016. Kaitan Kondisi Makroekonomi dengan Non Performing Financing Berdasarkan Sektor Ekonomi pada Perbankan Syariah di Indonesia. Jurnal Keuangan dan Perbankan, 20(1).

Otoritas Jasa Keuangan, 2016. Laporan Perkembangan Keuangan Syariah [WWW Document].

Purbaningsih, Y.P., 2014. The Effect of Liquidity Risk and Non-Performing Financing (NPF) Ratio to Commercial Sharia Bank Profitability in Indonesia. In: International Proceedings of Economics Development and Research (IPEDR).

Wiranatakusuma, D.\& J.D., 2017. Building an early warning towards the resilience of Islamic banking in Indonesia. Al-Iqtishad J. Ilmu Ekon. Syariah (Journal Islam. Econ. 9, 13-32. 